\title{
Ituglanis cahyensis, a new catfish from Bahia, Brazil (Siluriformes: Trichomycteridae)
}

\author{
Luisa M. Sarmento-Soares*, Ronaldo F. Martins-Pinheiro**, \\ Arion T. Aranda*** and Carine C. Chamon*
}

A new trichomycterid catfish of the genus Ituglanis is described from the rio Palmares, a tributary of the rio Cahy in southeast Bahia State, Brazil. Ituglanis cahyensis is distinguished from all other congeners through a combination of characters, as the supraorbital laterosensory canal branch with pores s3 and s6 present, the low count of branched pectoral fin rays, and low number of paired ribs. It is further distinguished in proportional measurements, such as elongate nasal, maxillary, and rictal barbels, and small eye diameter.

É descrito um novo trichomycterídeo do gênero Ituglanis, capturado no rio Palmares, um tributário do rio Cahy, na costa sudeste do estado da Bahia, Brasil. Ituglanis cahyensis distingue-se das demais espécies congêneres por uma combinação de caracteres, como o canal laterosensorial supraorbital com os poros s 3 e s6 presentes, um pequeno número de raios ramificados nas nadadeiras peitorais, e um pequeno número de costelas. Distingue-se ainda quanto a proporções morfométricas, como os barbilhões nasal, maxilar e rictal alongados, e o pequeno diâmetro ocular.

Key words: Catfish, Systematics, Trichomycterus, Freshwater, Southeastern Bahia.

\section{Introduction}

The genus Ituglanis was proposed by Costa \& Bockmann (1993) and defined on the basis of derived characters as: supraoccipital fontanel reduced to a small posterior round orifice; palatine with a deep concavity on its medial margin and anterior portion of sphenotic directed anteriorly. Comparatively, Ituglanis is an extremely important taxon to understand the major modifications undergone by several members of some trichomycterid subfamilies (de Pinna, 1998). Ituglanis is the sister group of a monophyletic clade composed by the subfamilies of the hematophagous Vandelliinae catfishes, the lepidophagous Stegophilinae, and also the Tridentinae, Sarcoglanidinae and Glanapteryginae (Costa \& Bockmann, 1993; de Pinna, 1998). The whole group shares a proportionally small number of pleural ribs: two to seven pairs, differing from the count of over eight ribs in other trichomycterids considered as primitive (Costa \& Bockmann, 1993; de Pinna, 1998; Fernández \& Bichuette, 2002).
The genus Ituglanis was erected to include nine species formerly assigned to Trichomycterus (Costa \& Bockmann, 1993; de Pinna \& Wosiacki, 2003). Nowadays the genus is composed by 17 species (see Table 1). Although de Pinna \& Keith (2003) suggested I. eichorniarum and I. herberti as conspecifics, we agree with Datovo \& Landim (2005) that both represent distinct species.

The BIOBAHIA project (Diversity, endemism and biogeography of catfishes in less explored aquatic systems in the extreme southern Bahia) aims to provide an inventory of the freshwater fishes of the hydrologic systems opening to the Atlantic at southern Bahia region. The project relied upon the cooperation of the Museu Nacional and the "All Catfish Species Inventory Project". A recent ichthyological survey towards northeastern Minas Gerais and southern Bahia rivers was undertaken and a peculiar species of Trichomycteridae was obtained, which upon examination revealed to be a new Ituglanis species, described herein.

\footnotetext{
* Setor de Ictiologia, Departamento de Vertebrados, Museu Nacional, Quinta da Boa Vista, 20940-040 Rio de Janeiro, RJ, Brazil. e-mail: luisa@nossacasa.net

**Projeto BIOBAHIA. Alto do rio do peixe pequeno, quadra 2, lote 14, Cumuruxatiba, 45983-000 Prado, BA, Brazil. e-mail: ronaldo@nossacasa.net ***Curador Técnico da Coleção de Simulídeos/LSO. Convênio FAPERJ/FIOCRUZ. Laboratório de Referência Nacional em Simulídeos e Oncocercose. Pavilhão Carlos Chagas, $4^{\circ}$ andar, sala 07. Instituto Oswaldo Cruz/FIOCRUZ. Rio de Janeiro, RJ, Brazil. e-mail: arion@ioc.fiocruz.br
} 
Table 1. Distribution of Ituglanis species.

\begin{tabular}{lll}
\hline & Species & Distribution \\
\hline 1 & Ituglanis amazonicus (Steindachner, 1882) & Amazon basin in Brazil and French Guiana \\
2 & Ituglanis bambui Bichuette \& Trajano, 2004 & Angelica Cave, São Domingos, Goiás, Brazil \\
3 & Ituglanis cahyensis new species & Rio Cahy drainage, Southern Bahia, Brazil \\
4 & Ituglanis eichorniarum (Miranda-Ribeiro, 1912) & Upper Paraguay basin in Brazil \\
5 & Ituglanis epikarsticus Bichuette \& Trajano, 2004 & São Mateus Cave in São Domingos, Goiás, Brazil \\
6 & Ituglanis gracilior (Eigenmann, 1912) & Guyana \\
7 & Ituglanis guayaberensis (Dahl, 1960) & Rio Guayabero basin, rio Orinoco drainage \\
8 & Ituglanis herberti (Miranda-Ribeiro, 1940) & Rio Bodoquena in Paraguay basin, Brazil \\
9 & Ituglanis laticeps (Kner, 1863) & Ecuador \\
10 & Ituglanis macunaima Datovo \& Landim, 2005 & Rio Araguaia basin \\
11 & Ituglanis metae (Eigenmann, 1917) & Colombia \\
12 & Ituglanis nebulosus de Pinna \& Keith, 2003 & French Guiana \\
13 & Ituglanis parahybae (Eigenmann, 1918) & Rio Paraíba do Sul and rio São João basins, Brazil \\
14 & Ituglanis parkoi (Miranda-Ribeiro, 1944) & Amazon basin in Brazil \\
15 & Ituglanis passensis Fernández \& Bichuette, 2002 & Passa Três Cave system, São Domingos, Goiás, Brazil \\
16 & Ituglanis proops (Miranda-Ribeiro, 1908) & Rio Ribeira de Iguape basin, Brazil \\
17 & Ituglanis ramiroi Bichuette \& Trajano, 2004 & São Bernardo Cave, São Domingos, Goiás, Brazil \\
\hline
\end{tabular}

\section{Material and Methods}

Straight-line measurements were taken under a stereomicroscope with a Mitutoyo digital caliper, and recorded in tenths of millimeter. Methodology and terminology for measurements followed Tchernavin (1944), de Pinna (1992), and Trajano \& de Pinna (1996). Standard length (SL) is expressed in milimeters. Specimens very old in collections such as MNRJ 782 were not considered suitable for measurements but nevertheless were analyzed regarding meristic features and external morphology. Meristic data were obtained from alcoholic and cleared and stained specimens. Fin rays were counted under a stereomicroscope. Dorsal and anal-fin ray counts included the two unbranched rays, visible when back lighted and subsequent branched rays; pectoral- and pelvic-fin rays included the first unbranched plus the branched rays. Vertebral counts follow de Pinna (1992). Branchiostegal ray and rib counts were performed in cleared and stained specimens and upon dissection of some specimens. Osteological examination was made on cleared and stained (C\&S) specimens according to the procedures of Taylor \& Van Dyke (1985). Terminology and nomenclature for osteological data followed Arratia \& Huaquin (1995) and Arratia (2003). Morphological information about I. gracilior, I. laticeps, I. nebulosus, and I. metae were based on digital photographic images (I) and radiographs (R). Morphological data about I. bambui, I. epikarsticus, I. guayaberensis, I. herberti, I. macunaima I. parkoi, I. passensis, and I. ramiroi were based on literature (Eigenmann, 1912; Miranda Ribeiro, 1944; Férnandez \& Bichuette, 2002; de Pinna \& Keith, 2003; Bichuette \& Trajano, 2004; Datovo \& Landim, 2005). Institutional abbreviations follow Leviton et al. (1985).
Ituglanis cahyensis, new species

Fig. 1
Holotype. MNRJ 28404 (48.6 mm SL), Brazil, Bahia: Prado, rio Palmares on road Guarany- Corumbau, in direction to Corumbau after the joint with the road to the mouth of rio Cahy, (16 $6^{\circ} 57^{\prime} 48^{\prime \prime} \mathrm{S}$ $\left.39^{\circ} 16^{\prime} 33^{\prime \prime W}\right), 24$ Oct 2004, L. M. Sarmento-Soares, A. T. Aranda, C. C. Chamon \& R. F. M. Pinheiro.

Paratypes. Brazil, Bahia: MNRJ 28405 (2 C\&S, 41.3-48.6 mm SL) collected with the holotype. MNRJ 28406 (1, $28.6 \mathrm{~mm} \mathrm{SL})$, Prado, rio Palmares on road Guarany-Corumbau, near Palmares (16 $6^{\circ} 56^{\prime} 25^{\prime \prime S}$ $\left.39^{\circ} 19^{\prime} 48^{\prime \prime} \mathrm{W}\right), 24$ Oct 2004, same collectors as holotype.

Diagnosis. The new species is distinguished from most of its congeners, except I. macunaima and I. parahybae, by the pectoral fin ray count of $i, 4$. The coloration pattern with longitudinal rows of coalescing blotches differentiate the new species from all its congeners, with the exception of I. parahybae, from whom it is distinguished by the supraorbital laterosensory canal branch with pores s3 and s6 present ( $v s$. pores $\mathrm{s} 3$ and $\mathrm{s} 6$ absent in I. parahybae).

Ituglanis cahyensis is distinguished from I. amazonicus by the higher number of ribs, four ( $v s$. three), by the supraorbital laterosensory canal lacking pore $\mathrm{s} 1$ ( $v s$. s1 pore present), and by the color pattern blotched (vs. uniformly colored, with grayish dots). From the subterranean species I. bambui, I. epikarsticus, I. passensis and I. ramiroi by the color pattern with round dark spots often coalescent and forming longitudinal rows ( $v s$. pale yellowish with no rows of dark pigmentation) and by the normally developed eyes, with orbital diameter corresponding to more than $7.0 \%$ of HL ( $v s$. less than $6.1 \%$ of HL). From I. eichorniarum by the low number of branched dorsal fin rays, seven (vs. eight), by the supraorbital laterosensory canal lacking pore s1 ( $v s$. s1 pore present), 


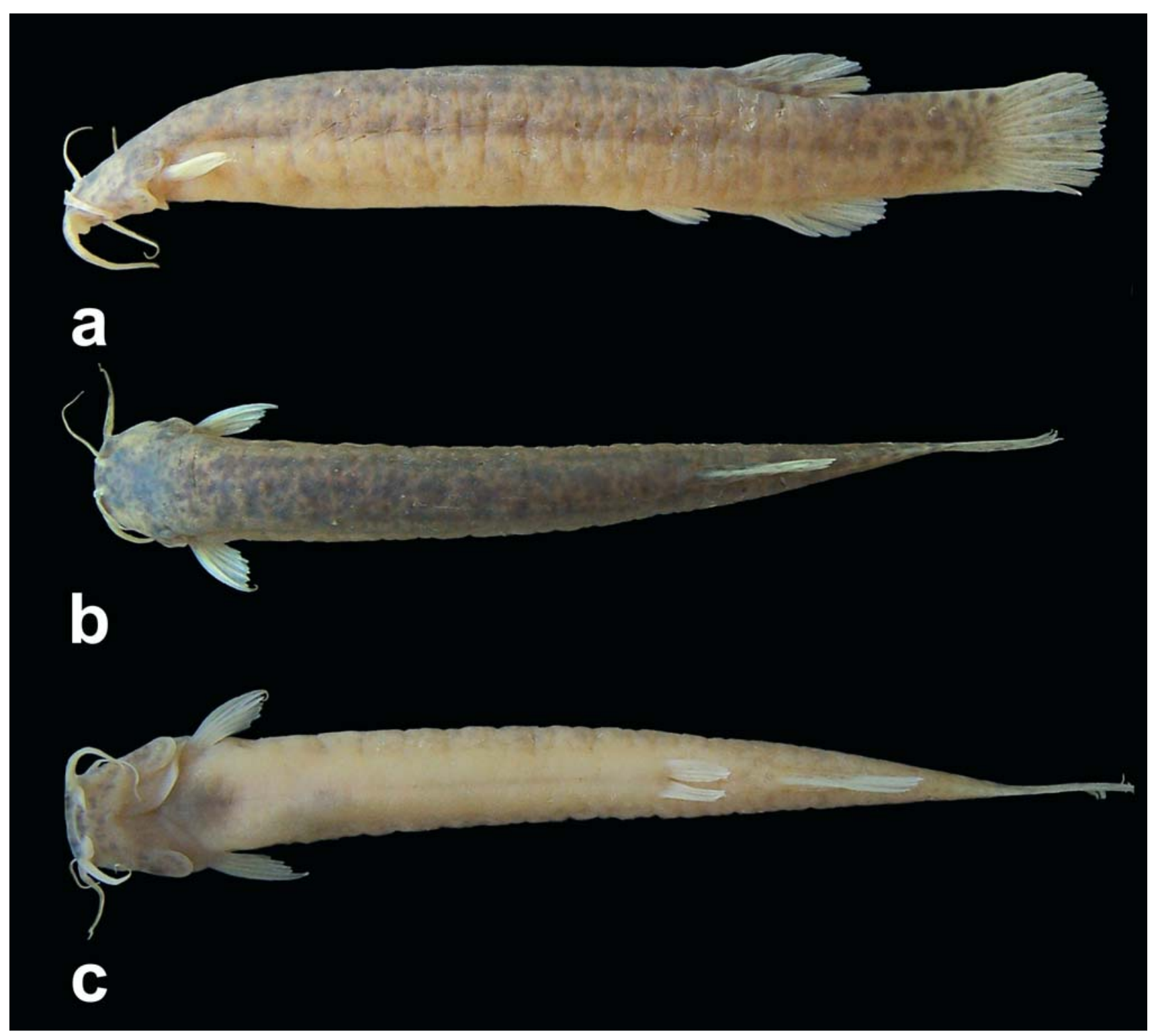

Fig. 1. Ituglanis cahyensis, holotype, MNRJ 28404, $48.6 \mathrm{~mm}$ SL. Rio Palmares on the road Guarany-Corumbau, Prado, Bahia, Brazil. a. lateral; b. dorsal; c. ventral views.

and by the color pattern with rows of dark blotches (vs. scattered small spots). From I. gracilior by the higher number of ribs, four (vs. two or three), by the low vertebral count, 40 (vs. 41-43), by the supraorbital laterosensory canal lacking pore s1 (vs. s1 pore present), and by the color pattern with longitudinal rows of coalescing blotches ( $v s$. scattered spots). From I. guayaberensis by the color pattern with longitudinal rows of coalescing blotches ( $v s$. scattered dark brown spots). From I. herberti by the supraorbital laterosensory canal lacking pore s1 (vs. s1 pore present), and by the color pattern with longitudinal rows of coalescing blotches ( $v s$. faint light brown spots). From I. laticeps by the pectoral fin ray counts i,4 (vs. $\mathrm{i}, 6)$, by the branched caudal fin rays $5 / 5$ or $5 / 6$ (vs. 6/7), by the high vertebral count, 40 (vs. 37) and by the color pattern with longitudinal rows of coalescing blotches on trunk (vs. obscure spots). From I. macunaima by the presence of a posterior cranial fontanel ( $v s$. absence), by the higher number of pleural ribs, four ( $v s$. two or three) and by the higher number of vertebrae, 40 (vs. 35-38). From I. metae by the pectoral fin rays i,4 (vs. i,5), by the low number of pelvic-fin rays i,3 ( $v s$. $\mathrm{i}, 4)$, by the branched caudal-fin rays $5 / 5$ or $5 / 6$ (vs. $6 / 6$ or $6 / 7$ ) and by the color pattern with longitudinal rows of coalescing blotches on trunk (vs. dark brown spots). From I. nebulosus by the pectoral-fin rays i,4 (vs. i,5), by the branched caudal fin rays $5 / 5$ or $5 / 6$ (vs. 6/6), by the number of ribs, four ( $v s$. five), by the higher vertebral count, 40 (vs. 35-36), by the supraorbital laterosensory canal lacking pore s1 ( $v s . \mathrm{s} 1$ pore present), and by the color pattern with longitudinal rows of coalescing 
blotches on trunk (vs. dark blotches not forming rows). From I. parkoi by the low number of pelvic-fin rays i,3 (vs. i,4), by the supraorbital laterosensory canal lacking pore s1 ( $v s$. s1 pore present), and by the color pattern with longitudinal rows of coalescing blotches on trunk ( $v s$. obscure spots not forming rows). Ituglanis cahyensis is distinguished from its geographically closest congeners, I. parahybae and I. proops, by the lower number of ribs, four (vs. six in both species), by differences on the extension and pores of supraorbital laterosensory canal (see below), and by some proportional measurements.

Ituglanis cahyensis share with I. proops a high number of vertebrae (40), and the supraorbital laterosensory canal with pores $\mathrm{s} 3$ and s6. The morphological similarity regarding supraorbital laterosensory canal is only superficial, as the number of pores in I. cahyensis is smaller compared to I. proops, as pores $\mathrm{s} 1$ and $\mathrm{s} 2$ are missing in the new species ( $v s$. present in I. proops). Ituglanis cahyensis and I. proops have different pectoral- and pelvic-fin ray counts. Four branched pectoral fin rays in the new species (vs. six in I. proops) and three branched pelvic fin rays (vs. four in I. proops). Ituglanis proops is a species with an adult size proportionally large, between 60-68.9 mm SL, in comparison to I. cahyensis, which attains adult size with about 40-48.6 mm SL. Ituglanis cahyensis has a proportionally elongated body, with a long preanal length, 70.3-73.3\% in SL, and a long prepelvic length, $59.3-62.6 \%$ in SL (vs. proportionally short body in I. proops, with preanal length $64.7-69.8 \%$ in SL and prepelvic length $52.2-58.1 \%$ in $\mathrm{SL}$ ). The new species is also distinct regarding the elongate barbels. The nasal, maxillary, and rictal barbels are longer than those of I. proops (see Table 2). Ituglanis cahyensis has short head measurements in comparison to $I$. proops, such as a short head width, 76.0-79.8\% in HL (vs. $82.4-87.9 \%$ HL in I. proops); a small eye diameter, $7.0-8.1 \%$ in HL (vs. 9.3-13.5\% HL in I. proops) and a small mouth width, $30.7-33.8 \%$ in HL (vs. 38.2-42.6\% HL in I. proops). The color pattern is also distinctive between the two species. The new species has spots often coalescent, forming longitudinal rows, while I. proops has scattered spots along the sides of body, not forming rows.

Ituglanis cahyensis is morphologically similar to I. parahybae, in several aspects. Both species share a low pectoraland pelvic-fin ray counts: four branched pectoral-fin rays and three branched pelvic-fin rays respectively, and also a similar color pattern (see discussion). Regarding meristic features the new species has seven branchiostegal rays ( $v s$. eight in I. parahybae), four paired ribs (vs. six in I. parahybae) and 40 vertebrae (vs. 38-39 in I. parahybae). In spite of the ob-

Table 2. Morphometric and meristic data for Ituglanis cahyensis (holotype MNRJ 28404; $\mathrm{n}=5)$, I. proops $(\mathrm{n}=8)$ and I. parahybae $(\mathrm{n}=6)$. Meristic data for I. parahybae also include MNRJ $782(\mathrm{n}=2)$.

\begin{tabular}{|c|c|c|c|c|c|c|c|c|}
\hline & \multicolumn{4}{|c|}{ I. cahyensis } & \multicolumn{2}{|c|}{ I. proops } & \multicolumn{2}{|c|}{ I. parahybae } \\
\hline & Holotype & Range & Mean & St.Dev. & Range & Mean & Range & Mean \\
\hline $\begin{array}{l}\text { Standard length }(\mathrm{mm}) \\
\text { Percents of SL }\end{array}$ & 48.6 & $28.6-48.6$ & 41.7 & 8.17 & $56.3-68.9$ & 63.6 & $32.7-44.5$ & 39.2 \\
\hline Total length & 113.0 & $111.1-115.7$ & 113.8 & 1.81 & $109.0-114.1$ & 111.2 & $107.7-116.2$ & 112.7 \\
\hline Body depth & 13.2 & $11.1-13.2$ & 12.3 & 0.83 & $10.9-12.2$ & 11.5 & $11.6-12.4$ & 11.9 \\
\hline Body width & 10.7 & $10.3-11.2$ & 10.7 & 0.42 & $8.6-14.2$ & 12.8 & $7.9-13.6$ & 10.5 \\
\hline Caudal peduncle depth & 10.3 & $8.4-10.3$ & 9.7 & 0.78 & $7.8-8.9$ & 8.3 & $7.9-10.8$ & 9.4 \\
\hline Caudal peduncle length & 18.3 & $16.4-19.5$ & 17.8 & 1.27 & $17.9-21.3$ & 20.0 & $15.5-18.6$ & 16.8 \\
\hline Predorsal length & 69.5 & $69.5-73.4$ & 71.3 & 1.55 & $66.8-70.0$ & 68.0 & $66.4-73.7$ & 71.2 \\
\hline Preanal length & 71.8 & $70.3-73.3$ & 71.9 & 1.28 & $64.7-69.8$ & 67.3 & $65.3-71.9$ & 69.2 \\
\hline Prepelvic length & 60.1 & $59.3-62.6$ & 60.8 & 1.68 & $52.3-58.1$ & 55.1 & $57.3-60.6$ & 59.2 \\
\hline Dorsal-fin base length & 10.3 & $10.2-10.9$ & 10.6 & 0.33 & $8.6-11.7$ & 10.0 & $10.2-11.6$ & 10.9 \\
\hline Anal-fin base length & 9.9 & $8.7-9.9$ & 9.2 & 0.47 & $9.0-13.1$ & 10.2 & $8.3-10.7$ & 9.6 \\
\hline Nasal barbel length & 12.8 & $12.8-16.8$ & 14.1 & 1.55 & $6.6-8.8$ & 7.5 & $8.8-13.5$ & 12.0 \\
\hline Maxillary barbel length & 14.6 & $14.5-18.2$ & 15.7 & 1.48 & $8.8-10.8$ & 9.7 & $12.9-15.9$ & 14.2 \\
\hline Rictal barbel length & 13.2 & $13.2-17.5$ & 14.5 & 1.77 & $6.3-9.5$ & 7.4 & $11.9-15.5$ & 13.6 \\
\hline $\begin{array}{l}\text { Head length } \\
\text { Percents of HL }\end{array}$ & 15.2 & $15.2-18.5$ & 16.9 & 1.57 & $12.8-15.8$ & 15.1 & $15.5-18.7$ & 16.8 \\
\hline Head width & 79.7 & $76.0-79.7$ & 78.4 & 1.65 & $82.4-87.9$ & 85.9 & $72.6-93.9$ & 81.0 \\
\hline Head depth & 44.6 & $41.3-44.6$ & 43.2 & 1.44 & $41.6-46.0$ & 43.3 & $27.3-38.1$ & 34.2 \\
\hline Interorbital distance & 29.7 & $25.3-29.7$ & 27.7 & 1.69 & $27.8-32.9$ & 31.2 & $25.8-29.5$ & 27.6 \\
\hline Internarial distance & 14.9 & $13.3-16.9$ & 15.3 & 1.37 & $13.7-17.6$ & 15.4 & $10.1-17.4$ & 12.5 \\
\hline Internarial width & 24.3 & $20.8-24.3$ & 22.7 & 1.65 & $20.8-25.9$ & 24.2 & $18.0-31.8$ & 23.7 \\
\hline Snout length & 37.8 & $33.3-37.8$ & 36.0 & 1.90 & $32.3-36.8$ & 34.7 & $29.0-34.8$ & 32.1 \\
\hline Orbital diameter & 8.1 & $7.0-8.1$ & 7.8 & 0.46 & $9.3-13.5$ & 11.6 & $9.1-11.5$ & 10.3 \\
\hline $\begin{array}{l}\text { Mouth width } \\
\text { Ray Counts }\end{array}$ & 31.1 & $30.7-33.8$ & 32.0 & 1.23 & $38.2-42.6$ & 40.9 & $27.3-39.1$ & 34.1 \\
\hline Total dorsal fin & ii, 7 & ii, 7 & & & ii,5-6 & & ii, 6 & \\
\hline Total pectoral fin & $\mathrm{i}, 4$ & $\mathrm{i}, 4$ & & & $\mathrm{i}, 6$ & & $\mathrm{i}, 4$ & \\
\hline Total ventral fin & $\mathrm{i}, 3$ & $\mathrm{i}, 3$ & & & $\mathrm{i}, 4$ & & $\mathrm{i}, 3$ & \\
\hline Total anal fin & ii,6 & ii,5-6 & & & ii, $4-5$ & & ii,5-6 & \\
\hline Total caudal fin & $5 / 6$ & $5 / 5$ or $5 / 6$ & & & $5 / 5$ or $5 / 6$ & & $5 / 6$ or $6 / 6$ & \\
\hline
\end{tabular}


served differences on meristic features, the ranges are very close between the two species. The two species are evidently distinct regarding the cephalic laterosensory system, as the supraorbital canal in I. cahyensis is extended along frontal bone, opening into pores $\mathrm{s} 3$ and s6, while in I. parahybae the entire supraorbital laterosensory canal is lacking (Costa \& Bockmann, 1993: fig. 3 a; Datovo \& Landim, 2005: 463; present paper). Ituglanis cahyensis is further distinguished from $I$. parahybae by the taller head depth, $41.3-44.6 \%$ in HL ( $v s$. $27.3-38.1 \%$ HL in I. parahybae) and by the small eye diameter, 7.0-8.1\% in HL (vs. 9.1- 11.5\% HL in I. parahybae).

Description. Morphometric and meristic data presented in Table 2. Body slim, trunk compressed, caudal peduncle laterally flattened. Dorsal profile of body ascent from tip of snout to anterior portion of trunk, approximately straight from that point to base of dorsal fin, descending along dorsal-fin base and straight on caudal peduncle until caudal fin. Ventral profile of head gently sloped. Ventral profile of body almost straight to somewhat convex.

Head small and slightly depressed. Eyes small, orbital margin not free. Skin covering eye thick, difficulting identification of eye in alcohol preserved specimens. Anterior nostril small surrounded by fleshy tube-shaped flap of integument. Posterior nostril larger surrounded anteriorly by raised fleshy flap and located slightly closer to anterior nostrils than to eye. Mouth inferior, lower lip contoured by conspicuous fleshy lobe medial to origin of rictal barbels. Upper lip with fleshy rictal fold. Nasal barbel originating on lateral portion of integumentary flap around anterior nostril; tip of barbel reaching opercular odontode patch. Maxillary and rictal barbels extend to pectoral-fin origin. Autopalatine with mesial margin notched, posteriorly expanded with wide lateral projection; maxilla well developed and curved. Premaxilla narrow, transversely elongated, meeting its counterpart medially. Jaws sub-equal; premaxilla and dentary almost straight with two well defined regular rows of short conical teeth. Branchiostegal membranes thick, united to isthmus only anteriorly.

Mesethmoid long, thin, with anterior border slightly convex, premaxillaries held underneath narrow anterior cornua through synchondral articulation. Lateral ethmoid projected laterally. Anterior cranial fontanel elliptical bounded by frontals (Fig. 2a). In smaller C\&S specimen narrow opening between frontals anteriorly to fontanel present, but closed in largest specimen. Minute supraoccipital fontanel represented by single posterior opening present. Antorbital very short slightly curved towards its distal portion. Fronto-lacrimal tendon-bone very long, rod-like, with short, sharp, lateral projection. Anterior portion of sphenotic-prootic-pterosphenoid projected anteriorly in dorsal view, giving off infraorbital sensory canal openings. Pterotic laterally projected. Posttemporo-supracleithrum small, giving off supraorbital laterosensory branch. Vomer arrow-shaped, narrow, with long lateral and posterior processes. Parasphenoid with long and pointed posterior process, reach-

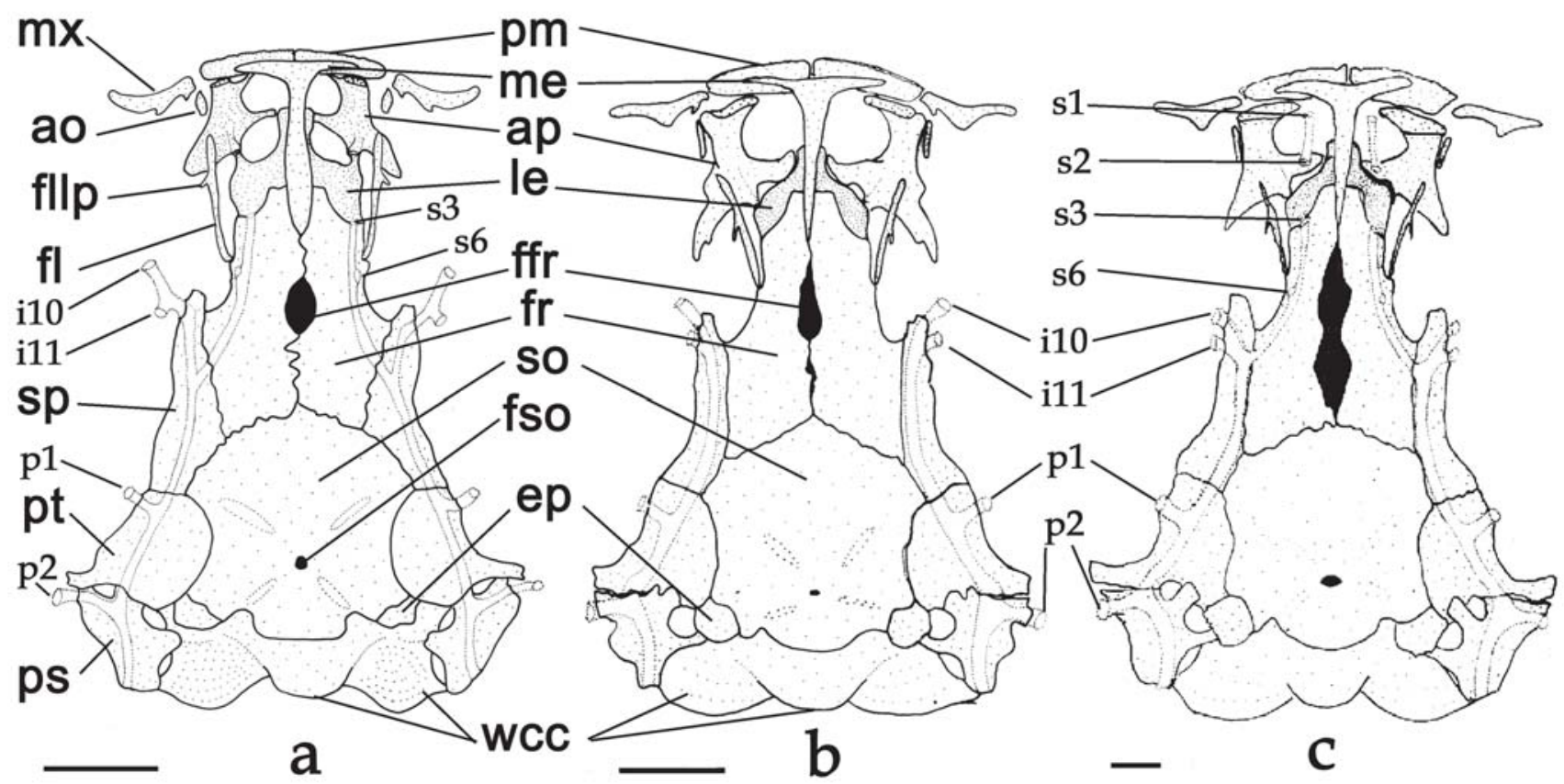

Fig. 2. Neurocranium and Weberian apparatus of: a. Ituglanis cahyensis, MNRJ 28405, paratype, 41.3 mm SL. b. Ituglanis parahybae, MNRJ 15413, 35.4 mm SL. c. Ituglanis proops MNRJ 13597, 60.5 mm SL. Dorsal view. Abbreviations: ao, antorbital; ap, autopalatine; ep, epioccipital; fr, frontal; ffr, frontal fontanel; fl, fronto-lacrimal tendon bone; fllp, fronto-lacrimal lateral process; fso, parieto-supraoccipital fontanel; i10, i11, infraorbital sensory pores 10 to 11; le, lateral ethmoid; me, mesethmoid; mx, maxilla; pm, premaxilla; ps, posttemporosupracleitrum; pt, pterotic; p1, p2, postotic sensory pores 1 to 2; so, parieto-supraoccipital; sp, sphenotic; s1, s2, s3, s6, supraorbital sensory pores 1 to 6; wcc, weberian complex and capsule. Scale bar $=1.0 \mathrm{~mm}$. 


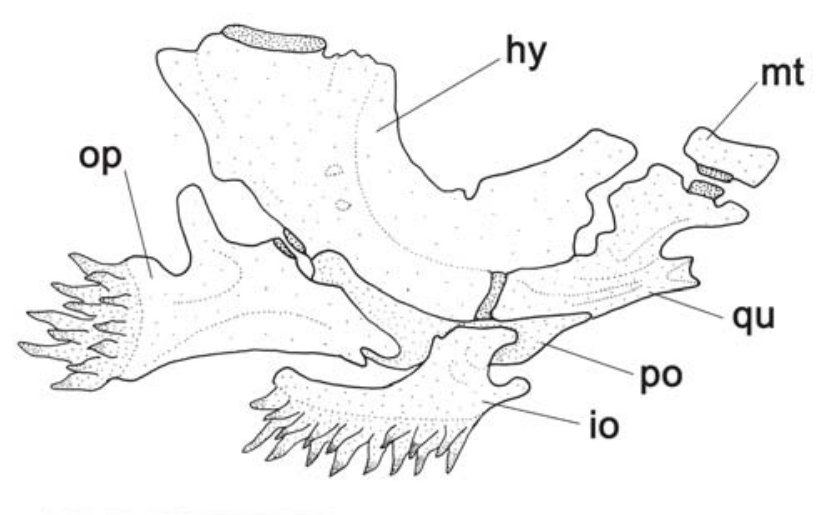

Fig. 3. Right suspensorium of Ituglanis cahyensis, MNRJ 28405, paratype, $41.3 \mathrm{~mm}$ SL. Lateral view. Abbreviations: hy, hyomandibula; io, interopercle; mt, metapterygoid; op, opercle; po, preopercle; qu, quadrate. Scale bar $=1.5 \mathrm{~mm}$.

ing middle of basioccipital-exoccipital. Anterior portion of Weberian complex fused to basioccipital-exoccipital.

Suspensorium with robust hyomandibula, projected anteriorly as membranous outgrowth. Laminar projection of hyomandibula anteriorly sutured to quadrate only, with no contact with metapterygoid. Metapterygoid short, laminar, almost rectangular joined to quadrate via anterior cartilage block only. Quadrate elongate, with broad base and anterior laminar projection through which this bone contacts to both hyomandibula and metapterygoid. Quadrate and hyomandibula contacted also through their broad bases and cartilaginous joint. Short preopercle sutured to ventral margins of both quadrate and hyomandibula. Opercular patch of odontodes small and roundish. Opercle with 9-12 elongate odontodes, posterior ones longest. Interopercular patch of odontodes narrow and reduced, with short anterior process. Interopercle with 16 odontodes arranged into two rows, 7-9 large odontodes in medial row and 7-9 smaller odontodes on lateral row (Fig. 3).

Urohyal well-developed with both long dorsal process and laminar surface, bearing conspicuous foramen. Hyoid arch with large ventral hypohyal, elongate anterior ceratohyal and somewhat triangular posterior ceratohyal, with markedly concave posterior face and with articulatory surface for interopercle. Posterior ceratohyal with small foramen in smaller c\&s specimen. Seven branchiostegal rays articulated with hyoid arch: three with anterior ceratohyal, two with interceratohyal cartilage between bones, and two with posterior ceratohyal. Brachiostegal rays 4 to 6 distally expanded and notched (Fig. 4). Dorsal hypohyal and interhyal absent.

Basibranchial 1 absent; basibranchial 2 and 3 with cartilaginous anterior and posterior tips, connected to each other forming osseous rod. Anterior cartilaginous tip of basibranchial axis reaches close to hipobranchial 1; posterior osseous tips nearly in contact with contralateral hypobranchial 3. Cartilage between basibranchial 2 and 3 is bordered laterally by cartilaginous head of hypobranchial 2. Basibranchial 4 hexagonal and completely cartilaginous bordered anteriorly by cartilaginous

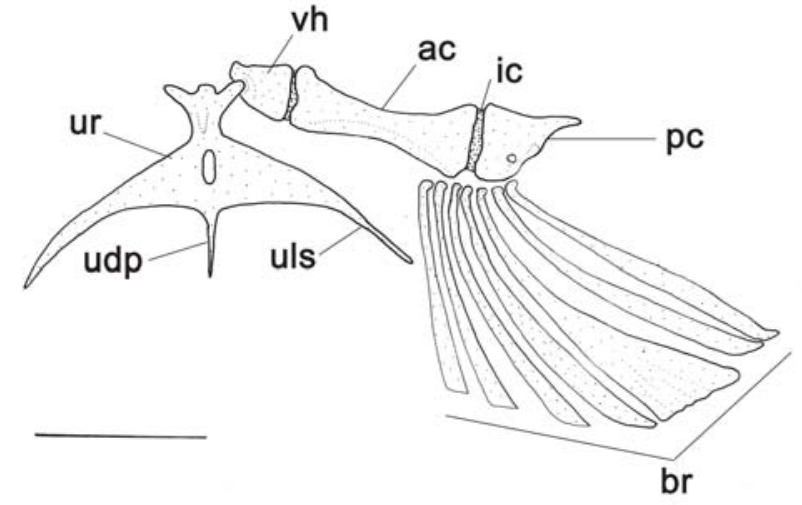

Fig. 4. Left hyoid arch of Ituglanis cahyensis, MNRJ 28405, paratype, $41.3 \mathrm{~mm}$ SL. Ventral view. Abbreviations: ac, anterior ceratohyal; br, branchiostegal rays; ic, interceratohyal cartilage; pc, posterior ceratohyal; vh, ventral hypohyal; udp, urohyal dorsal process; uls, urohyal laminar surface; ur, urohyal. Scale bar $=1.0 \mathrm{~mm}$.

head of ceratobranchial 4 and posteriorly by cartilaginous head of ceratobranchial 5. Hypobranchial 1 osseous, rod like, with cartilage on its proximal and distal tips. Hipobranchial 2 elongate, cartilaginous, almost trapezoid, with an osseous anterodistal process. Hypobranchial 3 approximately trapezoidal, mostly cartilaginous and closely positioned relative to its counterpart. Hypobranchial 4 absent. Five ceratobranchials present mostly ossified, with cartilage on their extremities. First ceratobranchials short, supporting one or two diminute rakers. Second and third ceratobranchials with shallow cavity in their posterior margins and mesial laminar extension. Fourth ceratobranchial almost straight. Fifth ceratobranchial with short proximal tip and anterior concavity, and slightly expanded posteromedially to support lower pharyngeal toothplate dorsally, with fine conical teeth arranged in 2 rows, with about 5 teeth in mesial row. Five epibranchials, first three-rod like, short and delicate, ossified; except for its cartilaginous extremities. Posterior margin of epibranchial 1 with small process. Epibranchial 2 with processes on its anterior and posterior margins. Epibranchial 3 with elongate posterior uncinate process. Epibranchial 4 broad, somewhat rectangular. Epibranchial 5 very small, completely cartilaginous, placed between posterior cartilaginous tips of epibranchial 4 and ceratobranchial 4. Pharyngobranchials 1 and 2 absent. Pharyngobranchial 3 elongate, ossified rod-like, with cartilaginous tips. Pharyngobranchial 4 ossified, giving support to upper pharyngeal tooth plate, with long conical teeth arranged in two rows; eight teeth on the main row (Fig. 5).

Cephalic sensory canals enclosed in bones, with some branches deeply embedded in those bones. Head sensory canals with simple tubes ending in single pores. All canals continuous and connected to each other. Supraorbital sensory canal running along frontal bone, deeply embedded in it. Supraorbital canal gives off two pores: pore s3 placed on anterior margin of frontal, and pore $\mathrm{s} 6$ on interorbital region. Supraorbital canal joining infraorbital canal in anterior part of 


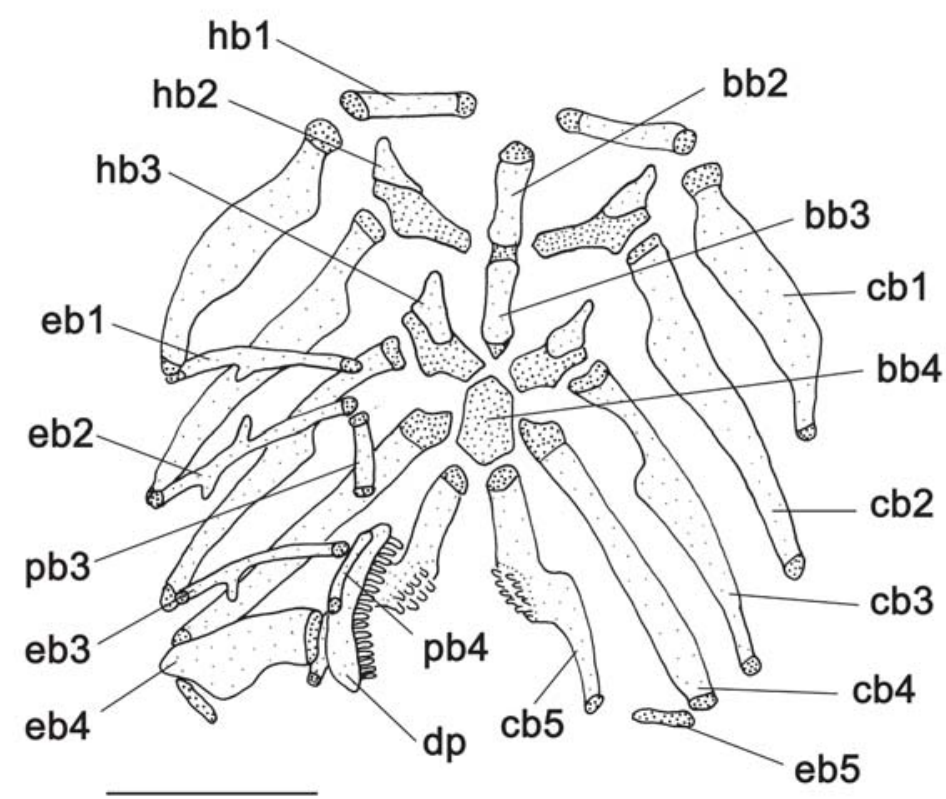

Fig. 5. Branchial skeleton of Ituglanis cahyensis, MNRJ 28405, paratype, $41.3 \mathrm{~mm}$ SL. Dorsal view (right dorsal elements and gill rakers not shown). Abbreviations: bb2 to bb4, basibranchial 2 to 4; cb1 to cb5, ceratobranchials 1 to 5; dp, dentigerous plate; eb1 to eb5, epibranchials 1 to 5 ; hb1 to hb3, hypobranchials 1 to 3 ; pb3 to pb4, pharyngobranchials 3 and 4 . Scale bar $=1.0 \mathrm{~mm}$.

sphenotic. Infraorbital canal incomplete, running along surface of head, reduced to its posterior segment. Infraorbital sensory canal gives off two pores, pores i10 and i11, present ventroposteriorly to eyeball. Temporal sensory canal extends from posterior limit of optic sensory canal to anterior limit of lateral line. Postotic canal with pores $\mathrm{p} 1$ and $\mathrm{p} 2$ (fig. 2). Preoperculo-mandibular sensory canal absent. Otic sensory canal short, without pores. Lateral line canal very short, with two pores, extending from posteriormost region of opercle to about level of anterior vertebrae.

Dorsal-fin margin somewhat rounded, with 2 unbranched plus 7 branched rays. Basal dorsal-fin radials 7 . Origin of dorsal fin on vertical of about $23^{\text {rd }}$ or $24^{\text {th }}$ vertebra. Pectoral fin with one unbranched plus 4 branched rays. Tip of first unbranched pectoral fin ray prolonged in filamentous portion. Pelvic fin very small, with one unbranched plus 3 branched rays and margin rounded. Pelvic fin originated on vertical of about $20^{\text {th }}$ vertebra. Anal fin with two procurrent rays; two unbranched rays plus 5-6 branched rays. Anal fin pterygiophores arranged in 6-8 elongate thin proximal radials and 5-6 very small completely cartilaginous distal radials. Caudal fin semi-truncated, $5 / 5$ or $5 / 6$ principal rays; dorsal lobe procurrent 12 ; ventral lobe procurrent 12 . Precaudal vertebrae 12 . Total vertebral count 40. Paired pleural ribs 4, becoming progressively small anteroposteriolly. First pleural rib slightly thick in comparison to subsequent ones; last fifth unpaired rib being present only on right side of body in both $\mathrm{C} \& \mathrm{~S}$ examined specimens.

Color in alcohol. Overall coloration remains visible, but ground color in ethanol becomes pale brown, with dark brown blotches and spots. Dorsal surface of head with groups of dark brown chromatophores, more concentrated on nape. Trunk with five rows of dark brown blotches: an unpaired middle row runs along dorsal portion of trunk, followed by two paired rows along latero-dorsal sides of body. Latero-ventral parts of body becoming gradually less scattered towards ventral parts. Nasal and maxillary barbels with chromatophores on their dorsal surface. Rictal barbel less pigmented on its proximal tip. Unpaired fins with light brown pigmentation concentrated on fin membrane. Pectoral fin with dark brown pigmentation limited to its basal part. Pelvic fins hyaline.

Live coloration. Ground color pale yellow, mottled with grayish brown blotches, coalescing irregularly, and spots, forming longitudinal rows on trunk. Two longitudinal rows of coalescing blotches on lateral sides of trunk, and one mid-dorsal row. Mid-dorsal row distinguished only on anterior portion of body, as blotches become progressively continue with lateral row close to dorsal-fin insertion. Head pale yellow to orange-yellow with scattered grayish brown chromatophores. Ventral surface of head and belly white. Fins almost hyaline. (Fig. 6).

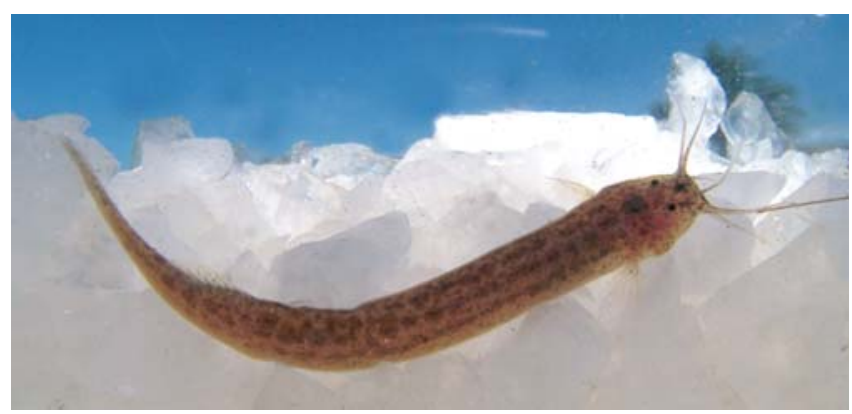

Fig. 6. Ituglanis cahyensis, new species. Specimen photographed alive in a field aquarium shortly after collection. 


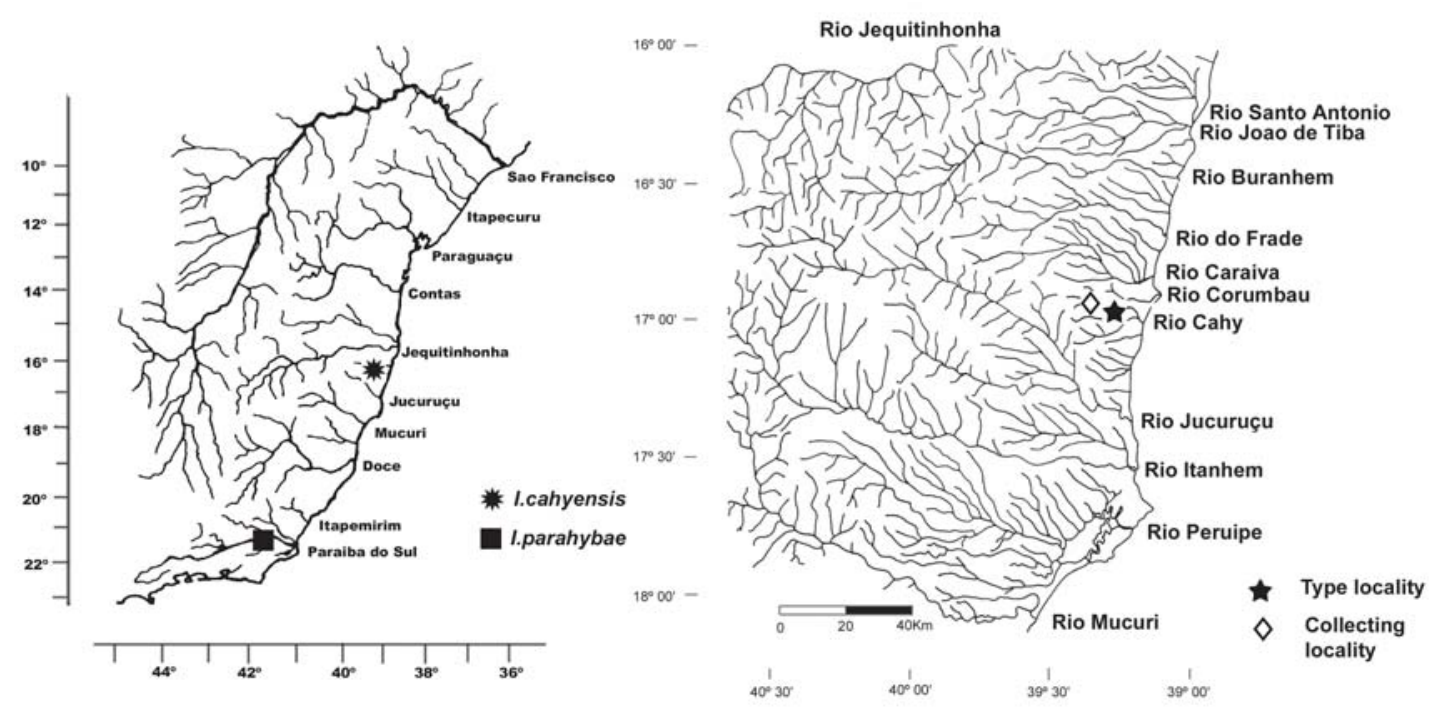

Fig. 7. Drainages of eastern Brazil between rio São Francisco and rio Paraíba do Sul, illustrating the distribution of the Ituglanis species in the area. Symbols may represent more than one locality. In detail, collecting localities of Ituglanis cahyensis in the study area, between the rio Mucuri and rio Jequitinhonha.

Distribution. Known only from rio Palmares a tributary of the rio Cahy, a small coastal river drainage from southeastern Bahia State in Brazil (Fig. 7).

Etymology. The specific name cahyensis is in reference to the rio Cahy, the main river of the basin where the new species was captured. The mouth of the rio Cahy is a place of great historical significance, as it is located near the point where the Portuguese navigator Pedro Alvarez Cabral and its fleet landed in Brazil for the first time in the year 1500.

Ecological notes. The rio Palmares is the northernmost tributary of the rio Cahy drainage, with shallow waters, with approximately $1.5 \mathrm{~m}$ of depth where the catfish samples were collected (Fig. 8). The small Ituglanis catfishes were sampled in brown waters, with moderate flowing current and a sandy

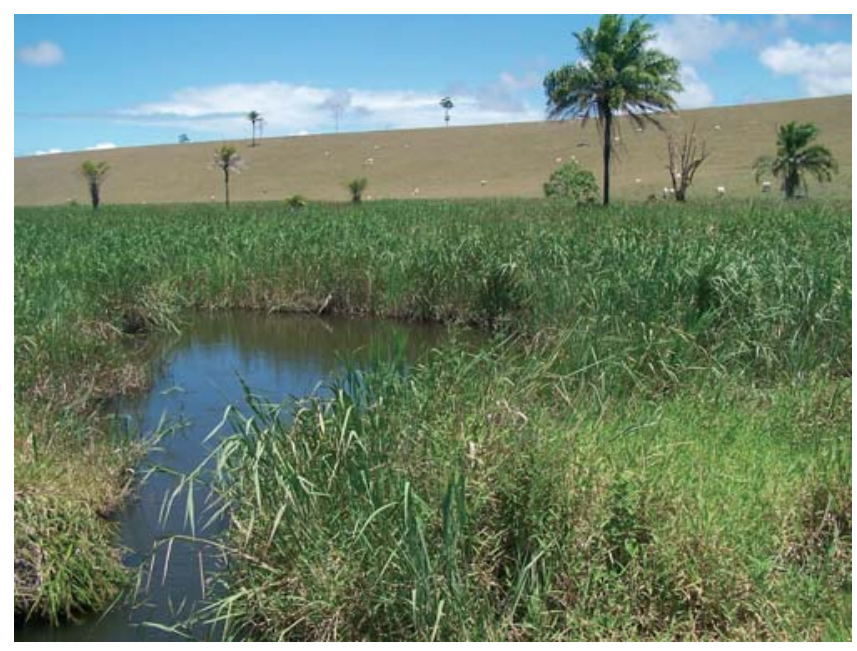

Fig. 8. Rio Palmares, a small stream, Prado, Bahia, northeastern Brazil, type locality of Ituglanis cahyensis. or gravel bottom. The environment around the river was deforested, with few floating meadows and moderately vegetated on its margins.

The stomach contents of two specimens were analyzed (MNRJ 28405, female, with unknown size due to a damaged caudal peduncle and MNRJ 28405, male, $41.3 \mathrm{~mm} \mathrm{SL}$ ). The stomachs were partially empty, but with remaining fragments of insect larvae, nymphs, and organic matter in advanced state of digestion. The macroscopic examination of gonads of both specimens revealed that the female was in maturing stage, while the male was in depletion stage, an indicative that the small catfishes were reproducing by the time of their capture.

\section{Discussion}

The genus Ituglanis is suspected to be a monophyletic clade, but the limits of most of its species remains poorly known (de Pinna \& Keith, 2003). The new species is undoubtedly placed in Ituglanis due to the presence of the three synapomorphies postulated by Costa \& Bockmann (1993): (a) the vestigial condition of the posterior fontanel, reduced to a small round opening on the posterior portion of parieto-supraoccipital; (b) a deep notch on the mesial margin of autopalatine; and (c) proximal portion of sphenotic anteriorly directed. All those characters are present in I. cahyensis and can be seen in Fig. 2a. External morphological characters for Ituglanis according to Costa \& Bockmann (1993) and observed in I. cahyensis include the presence of a reduced interopercular odontode plate; subterminal mouth; nasal, commissural, and maxillary barbels long; eyes of moderate size; pelvic fin present and anal fin placed at vertical through dorsal-fin base.

Inferences on relationships among Ituglanis species are given in de Pinna \& Keith (2003), with the suggestion of two main monophyletic groups within the genus, commented in the contribution of Datovo \& Landim (2005). One proposed 
monophyletic group includes northern South American species from the Amazon and the Guyanas, as I. amazonicus, I. gracilior, I. nebulosus, and an undescribed species from Amazon. Those forms share a peculiar widening of the mesethmoid shaft and, according to Datovo \& Landim (2005), a reduced number of 2-3 pleural ribs. The second monophyletic group includes southern forms from the Paraná/Paraguai, Ribeira do Iguape, Paraíba do Sul, southeastern drainages in Brazil and Uruguay, and two southern Amazonian forms, as $I$. eichorniarum, I. parahybae, I. proops, and two undescribed species from rio Uruguay and rio Tocantins basins. Those species share a derived process on the fronto-lacrimal tendon bone and, according to Datovo \& Landim (2005), have a large number of pleural ribs, 5-7. The inclusion of I. eichorniarum as a member of the second monophyletic group was questioned by Datovo \& Landim (2005), as the examined specimens revealed to have only two pleural ribs. In Ituglanis cahyensis there is a narrow mesethmoid shaft, thus discarding the placement of this species in the first monophyletic group. On the other hand, a peculiar lateral process on the anterior third of the antorbital is present (Fig. 2a, fllp), which approaches I. cahyensis to the second monophyletic assemblage postulated by de Pinna \& Keith (2003). However, the possession of four pleural ribs by $I$. cahyensis is intermediate between the two monophyletic groups. Elucidation of the relationships of I. cahyensis within Ituglanis is desirable through a phylogenetic analysis, preferably associated with a species level revision. We agree with Datovo \& Landim (2005) that a proposal of relationships among the Ituglanis specimens is premature for the time.

In the new species the anterior cranial fontanel is of intermediate size between that of I. parahybae and of I. proops. In I. parahybae it is a narrow opening between the frontals, but in I. proops it is much wider, sometimes reaching the supraoccipital (compare Figs. 2 a, b, c). In I. proops, however, a variation in extension of this fontanel was detected, as some individuals have a shorter fontanel, restricted to frontals while others have an opening extending until the supraoccipital. The presence of a wide opened anterior cranial fontanel was observed also in $I$. amazonicus, a species with an intra-specific variation in size of the cranial fontanel opening, in a similar manner as detected for I. proops. Ituglanis amazonicus is quite distinct from the new species regarding meristic features and the color pattern. The new species does have spots on the sides of body, while $I$. amazonicus has small grayish dots.

The presence of a high number of vertebrae in I. cahyensis, 40 , is a common feature among the Ituglanis. Most examined Ituglanis species have more than 38 vertebrae, as was observed for I. amazonicus, 39, I. eichorniarum, 38-39, I. gracilior, 41, I. laticeps, 38-42, I. metae, 42, I. parahybae, 39 and $I$. proops, 38-40. A high vertebral count was also recorded in literature for I. herberti and I. parkoi (Datovo \& Landim, 2005). Among the 17 species in Ituglanis, including the new $I$. cahyensis, 10 have high vertebral count. The only species with no information available regarding osteological features is I. guayaberensis. These findings contradict the observations by de Pinna \& Keith (2003), who considered that most
Ituglanis species have 39 vertebrae or less.

A pectoral fin ray count of $\mathrm{i}, 4$, found in I. cahyensis, is considered low within the genus, found only in I. parahybae, I. macunaima, and in some I. eichorniarum. Most Ituglanis species have i,5 or i, 6 pectoral fin rays.

Specimens of Ituglanis cahyensis have i,3 pelvic-fin rays, a common count in the genus. In I. parahybae the pelvic-fin ray counts vary between i,3 and i,4. A vestigial fifth branched pelvic-fin ray was found in some I. parahybae, what may be an indicative of a trend to pelvic fin reduction. Some specimens of I. parahybae have been reported to lack those fins completely (Costa \& Bockmann, 1993; de Pinna \& Keith, 2003). In I. cahyensis no vestigial rays were observed on pelvics, and those fins were always present, with invariably the same fin ray count.

It was observed a low number of paired ribs in I. cahyensis, 4, plus an unpaired reduced rib in the right side of the body, seen in both two C\&S specimens. Such a case may be an indicative of a tendency to rib reduction within the I. cahyensis. Most Ituglanis species have a short rib count. In $I$. amazonicus, I. eichorniarum, I. gracilior, I. macunaima, and I. nebulosus, there are 2-3 ribs. Among the examined I. proops and I. parahybae, the rib count varied between 6-7 paired ribs. In comparison to the congeners from southeastern Brazilian rivers, I. cahyensis has a low rib count. In spite of the differences in rib count, the color pattern between I. cahyensis and I. parahybae is much similar. Regarding the color pattern both species have round dark spots, on dorsum and sides of the body, often coalescent and forming longitudinal rows. The number of longitudinal rows of coalescing blotches on lateral sides of trunk may be arranged into two rows, in $I$. cahyensis or in two or three rows in I. parahybae (de Pinna \& Keith, 2003: 874; Datovo \& Landim, 2005: 462; present paper).

The cephalic sensory system gives off different branches and pores which may be significantly distinct for some catfish groups (Arratia \& Gayet, 1995). The lateralis system comprises the main lateral line, postotic, otic, supraorbital, infraorbital, preopercular, and mandibular canals in primitive catfishes, such as the diplomystids (Arratia \& Huaquin, 1995). In trichomycterids an interrupted lateralis system loosing parts of the supraorbital, infraorbital and preoperculo-mandibular canals is observed (Arratia \& Huaquin, 1995). Among Trichomycterus species the supraorbital canal may be complete or interrupted. Within Ituglanis, we observed a trend to loose some segments of the cephalic sensory system, including the entire loss of the supraorbital canal or at least part of its branches. The supraorbital canal runs along the frontal and nasal bones in Ituglanis proops, with pores s1,s2, s3 and s6 present (Fig. 2c). An interruption of the supraorbital canal between the frontal and nasal bones was observed in $I$. proops. Such a case of a canal interruption was observed for Ochmacanthus and Vandelia by Arratia (1990). An extreme case of the cephalic sensory canal reduction was observed in Silvinichthys, where the only openings present are pores s1 and s2 along nasal bone (Arratia, 1998). In Ituglanis cahyensis the supraorbital is limited to frontal, with pores s3 and s6 present (Fig. 2a). In I. parahybae the complete supraorbital 
canal is absent (Fig. 2b). The entire supraorbital canal is lost in certain trichomycterids such as Glanapteryx (de Pinna, 1989) and Listrura (de Pinna, 1988). The lack of a supraorbital canal in I. parahybae was illustrated in Costa \& Bockmann (1993: fig. 3) and was commented by Datovo \& Landim (2005: $463)$ as being a reductive character within the genus. Arratia $\&$ Huaquin (1995) considered the patterns of pores on the supraorbital canal to be diagnostic of certain trichomycterids, and this seems to be the case for at least the Ituglanis species from southeastern Brazilian coastal drainages.

Comparative material. Ituglanis amazonicus: MNRJ 15402, 2; USNM 199220, 1, (I, R); USNM 263929, 1 (I, R); USNM 263930 , 1 (I, R); USNM 300990, 1 (I, R); USNM 305468, 2 (I, R); USNM 317738, 3 (I, R); USNM 319600, 1 (I, R); I. eichorniarum: CAS 77022, 2 (I, R); MNRJ 15401, 2; I. gracilior: FMNH 53264, 1 (18.0 mm SL), holotype (I, R); I. laticeps: USNM 163908, 1 (I, R); I. metae: CAS 118214, 2 (I, R); I. nebulosus: MNHN 2001-1128, 1 (I, R), holotype; I. parahybae: MNRJ 782, 2 (40.0- 40.9 mm SL); MNRJ 15413, 4 (32.7-44.5 mm SL), 1 c\&s. MZUSP 79810, 1 (41.9 mm SL); I. proops: FMNH 58576, holotype (I, R); MNRJ 13597, 9 (56.3-68.9 mm SL), 1 c\&s, topotypes; Ituglanis sp.: MNRJ 22763, 3 (27.4- 40.9 mm SL); MNRJ 22765, 1 (29.4 mm SL).

\section{Acknowledgments}

We wish to thank our colleagues in the Setor de Ictiologia of the Museu Nacional, and in special Gustavo W. Nunan, Paulo A. Buckup, and Priscila M. Gomes. For photographs and radiographs of species we are indebted to Kevin Swagel, Jon Fong, and Sandra Raredon. We wish to thank Mélyne Hautecoeur (http://www.mnhn.fr/collections) and the All Catfish Webpage, (http://silurus.acnatsci.org) for the availability of images on catfish types. We are grateful to Marcelo R.S. Melo for his cooperation in providing references otherwise difficult for us to have access. Funding for the fieldwork was provided by the All Catfish Species Inventory Project, supported by the National Science Foundation, NSF DEB-0315963. We are also indebted to the Instituto Brasileiro do Meio Ambiente e dos Recursos Naturais Renováveis (IBAMA) for the regional collection permit within the study area.

\section{Literature Cited}

Arratia, G. 1990. Development and diversity of the suspensorium of the trichomycterids and comparison with loricarioids (Teleostei, Siluriformes). Journal of Morphology, 205: 193- 218.

Arratia, G. 1998. Silvinichthys, a new genus of trichomycterid catfishes from the Argentinian Andes, with redescription of Trichomycterus nigricans. Ichthyological Exploration of Freshwaters, 9(4): 347-370.

Arratia, G. 2003. Catfish head skeleton. An overview. Pp. 20-46 in: Arratia G, Kapoor B.G., Chardon M., Diogo R. (eds). Catfishes. Enfield, USA: Science Publishers Inc.

Arratia, G. \& M. Gayet. 1995. Sensory canals and related bones of Tertiary siluriform crania from Bolívia and North America and comparison with Recent forms. Journal of Vertebrate Paleontology, 15: 482-505.
Arratia, G. \& L. Huaquin. 1995. Morphology of the lateral line system and of the skin of diplomystid and certain primitive loricarioid catfishes and systematic and ecological considerations. Bonner Zoologische Monographien, 36: 1-110.

Bichuette, M. E. \& E. Trajano. 2004. Three new subterranean species of Ituglanis from Central Brazil (Siluriformes, Trichomycteridae). Ichthyological Exploration of Freshwaters, 15(3): 243-256.

Costa, W. J.E. M. \& F.A. Bockmann. 1993. Un nouveau genre néotropical de la famille des Trichomycteridae (Siluriformes: Loricarioidei). Revue Française d'Aquariologie et Herpetologie, 20(2): 43-46.

Datovo, A. \& M. I. Landim. 2005. Ituglanis macunaima, a new catfish from the rio Araguaia basin, Brazil (Siluriformes: Trichomycteridae). Neotropical Ichthyology, 3(4): 455-464.

Eigenmann, C. H. 1912. The freshwater fishes of British Guiana, including a study of the ecological grouping of species, and the relation of the fauna of the plateau to that of the lowlands. Memories of the Carnegie Museum, 5(1): 1-578.

Fernández, L. \& M. E. Bichuette. 2002. A new cave dwelling species of Ituglanis from the São Domingos karst, central Brazil (Siluriformes: Trichomycteridae). Ichthyological Explorations of Freshwaters, 13(3): 273-278.

Leviton, A. E., R. H. Gibbs Jr., E. Heal \& C. E. Dawson. 1985. Standards in Herpetology and Ichthyology. Part I. Standard Symbolic Codes for Institutional Resource Collections in Herpetology and Ichthyology. Copeia, 1985: 802-832.

Miranda Ribeiro, P. 1944. Um pigidídeo do alto Amazonas. Boletim do Museu Nacional, Nova Série, 19: 1-3.

de Pinna, M. C. C. 1988. A new genus of trichomycterid catfish (Siluroidei, Glanapteryginae), with comments on its phylogenetic relationships. Revue Suisse de Zoologie, 95: 113-128.

de Pinna, M. C. C. 1989. A new sarcoglanidine catfish, phylogeny of its subfamily, and an appraisal of the phyletic status of the Trichomycterinae (Teleostei, Trichomycteridae). American Museum Novitates, 2950: 1-39.

de Pinna, M. C. C. 1992. A new subfamily of Trichomycteridae (Teleostei, Siluriformes), lower loricarioid relationships and a discussion on the impact of additional taxa for phylogenetic analysis. Zoological Journal of the Linnean Society, 106: 175-229.

de Pinna, M. C. C. 1998. Phylogenetic relationships of Neotropical Siluriformes (Teleostei: Ostariophysi); historical overview and synthesis of hypothesis. Pp. 279- 330 in: Malabarba L. R., Reis R. E., Vari R. P., Lucena C. \& Lucena M. (eds.), Phylogeny and classification of neotropical fishes. Edipucrs, Porto Alegre, Brazil.

de Pinna, M. C. C. \& P. Keith, 2003. A new species of the catfish genus Ituglanis from French Guyana (Osteichthyes: Siluriformes: Trichomycteridae). Proceedings of the Biological Society of Washington, 116(4): 873-882.

de Pinna, M. C. C. \& W. Wosiacki. 2003. Trichomycteridae. Pp. 270-290, in: Reis R. E., Kullander S. O., and Ferraris, Jr. C. J. (eds.), Check list of the freshwater fishes of South and Central America. Edipucrs, Porto Alegre, Brazil.

Taylor, W. R. \& G. C. van Dyke. 1985. Revised procedures for staining and clearing small fishes and other vertebrates for bone and cartilage study. Cybium, 9(2): 107-119.

Tchernavin, V. V. 1944. A revision of some Trichomycterinae based on material preserved in the British Museum (Natural History). Proceedings of the Zoological Society of London, 114(1-2): 234-275.

Trajano, E. \& M. C. C. de Pinna. 1996. A new cave species of Trichomycterus from eastern Brazil (Siluriformes, Trichomycteridae). Revue Française d'Aquariologie et Herpetologie, 23(3-4): 85-90.

Received November 2005 Accepted August 2006 